\title{
Korelasi Jumlah Folikel Antral dengan Kadar 25(OH)D Serum pada Penderita Sindrom Ovarium Polikistik
}

\author{
Asri Dini Mustari, ${ }^{1}$ Tiene Rostini, ${ }^{2}$ Agnes Rengga Indrati, ${ }^{2}$ Hartanto Bayuaji, ${ }^{3}$ Sylvia Rachmayati ${ }^{2}$ \\ ${ }^{1}$ Dinas Kesehatan Kabupaten Bandung Barat, Indonesia, ${ }^{2}$ Departemen Patologi Klinik Fakultas Kedokteran \\ Universitas Padjadjaran/Rumah Sakit Dr. Hasan Sadikin Bandung, Indonesia, ${ }^{3}$ Departemen Obstetri Ginekologi \\ Fakultas Kedokteran Universitas Padjadjaran/Rumah Sakit Dr. Hasan Sadikin Bandung, Indonesia
}

\begin{abstract}
Abstrak
Sindrom ovarium polikistik (SOPK) ditandai oleh hiperandrogenisme, oligo atau anovulasi, dan morfologi ovarium polikistik. Penanda ovarium polikistik, yaitu terdapat $\geq 12$ folikel antral dengan diameter $2-9 \mathrm{~mm}$ pada pemeriksaan ultrasonografi. Vitamin D (25-hidroksivitamin D; 25(OH)D) berperan pada proses steroidogenesis di sel teka ovarium dan pengaturan ekspresi reseptor follicle stimulating hormone (FSH) di sel granulosa ovarium. Defisiensi 25(OH)D menyebabkan penurunan aktivitas FSH, sehingga folikel antral di ovarium berukuran kecil dan berjumlah banyak. Tujuan penelitian ini mengetahui korelasi jumlah folikel antral dengan kadar 25(OH)D serum pada penderita SOPK. Uji observasional analitik dengan rancangan potong lintang di Rumah Sakit Umum Pusat Dr. Hasan Sadikin (RSHS) Bandung dilakukan selama bulan September 2017-Juni 2018. Subjek penelitian adalah 52 penderita SOPK yang telah didiagnosis oleh klinisi obstetri dan ginekologi RSHS Bandung. Pengambilan darah vena dilakukan untuk pemeriksaan kadar 25(OH)D serum dengan metode ELISA. Hasil penelitian ini mendapatkan 56\% subjek memiliki kadar 25(OH)D serum $\leq 20 \mathrm{ng} / \mathrm{mL}$. Hasil uji korelasi Spearman didapatkan korelasi negatif kuat yang bermakna $(r=-0,867, p<0,001)$ jumlah folikel antral dengan kadar 25(OH)D serum. Kadar 25(OH)D serum yang rendah pada penderita SOPK berkorelasi dengan jumlah folikel antral yang banyak. Terdapat korelasi negatif antara jumlah folikel antral dan kadar 25(OH)D serum pada penderita SOPK.
\end{abstract}

Kata kunci: Folikel antral, 25(OH)D serum, sindrom ovarium polikistik

\section{Correlation between Antral Follicles Count and Serum 25(OH)D Levels in Polycystic Ovary Syndrome Patients}

\begin{abstract}
Polycystic ovary syndrome (PCOS) is characterized by hyperandrogenism, oligo- or anovulation, and polycystic ovarian morphology. Vitamin D (25-hydroxyvitamin D; 25(OH)D) plays a role in the steroidogenesis process in the ovarian theca cells and regulates follicle stimulating hormone (FSH) receptor expression in granulosa cells. In 25(OH)D deficiency there is a decrease in FSH activity that the follicles become small and the antral follicles count in the ovary increases. The aim of this study was to determine the relationship between antral follicles count and serum 25(OH)D levels in PCOS patients. A cross-sectional analytical observational study was conducted in Dr. Hasan Sadikin General Hospital Bandung in September 2017-June 2018. Subjects of this study were 52 PCOS patients diagnosed by obstetricians and gynecologists of the hospital. Blood vein samples were collected to examine serum 25(OH)D levels using ELISA method. Serum 25(OH)D level of $\leq 20 \mathrm{ng} / \mathrm{mL}$ was found in $55.8 \%$ of the subjects in this study. Analysis using Spearman's correlation test showed a significant negative correlation ( $\mathrm{r}$ $=-0.867, \mathrm{p}<0.001)$ between antral follicles count and serum 25(OH)D level in patients with PCOS. Lower levels of 25(OH)D serum in PCOS patients correlates with higher number of antral follicles count. There is a negative correlation between antral follicles count and serum 25(OH) D level in PCOS patients.
\end{abstract}

Key words: Antral follicle count, 25(OH)D serum levels, polycystic ovary syndrome

Korespondensi: Asri Dini Mustari, dr., Dinas Kesehatan Kabupaten Bandung Barat, Komplek Pemda Bandung Barat Kp. Cijamil Ds. Mekarsari Kecamatan Ngamprah Bandung Barat, Jawa Barat, Email: asri.fk98@gmail.com 


\section{Pendahuluan}

Sindrom ovarium polikistik (SOPK) adalah kelainan endokrinologi yang ditandai oleh oligo atau anovulasi, hiperandrogenemia, dan morfologi ovarium polikistik. Sindrom ini juga berkaitan dengan kelainan hormonal yang memengaruhi kesehatan wanita usia reproduksi dan menyebabkan infertil. ${ }^{1}$

World Health Organization (WHO) pada tahun 2012 memperkirakan sekitar 116 juta wanita $(3,4 \%)$ mengalami SOPK di seluruh dunia. Prevalensi SOPK pada tahun 2016 sebanyak 6-21\% pada wanita usia reproduksi di seluruh dunia. ${ }^{2,3}$ Santoso dkk. ${ }^{4}$ menyatakan prevalensi SOPK pada wanita usia reproduksi sebanyak 4,5\%. Terdapat tiga kriteria diagnosis SOPK, yaitu Kriteria National Institutes of Health (NIH), kriteria Androgen Excess and Polycystic Ovarian Syndrome Society (AE-PCOS), dan kriteria Rotterdam. Kriteria Rotterdam adalah konsensus yang dihasilkan dari konferensi yang diselenggarakan oleh European Society for Human Reproduction and Embryology/the American Society for Reproductive Medicine (ESHRE/ASRM) pada tahun 2003. Diagnosis SOPK ditegakkan dengan kriteria Rotterdam apabila ditemukan dua dari tiga kriteria berikut, yaitu disfungsi ovarium, manifestasi hiperandrogen, dan gambaran morfologi ovarium yang polikistik. Kriteria Rotterdam merupakan kriteria yang dipergunakan dalam konsensus penanganan infertilitas di Indonesia. ${ }^{5,6}$

Gangguan hormonal reproduksi sering ditemukan pada SOPK. Peningkatan fungsi lutheinizing hormone (LH) merupakan faktor yang penting pada patofisiologi SOPK yang menyebabkan sel teka ovarium memproduksi hormon androgen berlebih sehingga terdapat keadaan hiperandrogenisme. Keadaan hiperandrogenisme menyebabkan gangguan pada perkembangan folikel ovarium sehingga proses pematangan folikel terhambat. Kondisi ini menyebabkan pertumbuhan folikel terhenti pada ukuran diameter 2-9 $\mathrm{mm}$ dan menghasilkan gambaran ovarium polikistik. ${ }^{7}$

Parameter yang diperiksa menggunakan ultrasonografi (USG) adalah jumlah folikel antral, yaitu folikel yang terlihat pada awal siklus menstruasi pada hari kedua hingga hari ke lima siklus menstruasi, diameter 2-9 $\mathrm{mm}$ yang dapat diperiksa menggunakan alat USG. Jumlah folikel antral di ovarium merupakan parameter penting dalam mendiagnosis SOPK. ${ }^{8}$

Vitamin D atau 25-hidroksivitamin D $(25(\mathrm{OH})$ D) memiliki peran pada sistem reproduksi wanita termasuk pada ovarium. Peran vitamin D pada ovarium diawali dengan ditemukannya reseptor vitamin D pada ovarium manusia. Vitamin D berperan pada sel teka ovarium, yaitu mengatur ekspresi reseptor FSH di sel granulosa ovarium dan mengatur proses steroidogenesis. Defisiensi vitamin $\mathrm{D}$ berpengaruh pada steroidogenesis yang menyebabkan keadaan hiperandrogenisme. Defisiensi vitamin D juga dapat menyebabkan aktivitas FSH menurun sehingga memengaruhi perkembangan serta pematangan folikel. ${ }^{9}$ Berdasar atas data penelitian terdahulu terdapat hubungan antara defisiensi kadar vitamin D dan insidensi SOPK. Nikhbakht dkk. ${ }^{10}$ menyatakan bahwa pada penderita SOPK terdapat defisiensi vitamin D dibanding dengan populasi kontrol $13(11,5) \quad \mathrm{ng} / \mathrm{mL}$ versus 25,07(20,7) ng/ $\mathrm{mL}$ ). Penelitian terhadap masalah ini belum ditemukan di Indonesia. Penelitian ini bertujuan mengetahui korelasi antara kadar 25(OH)D serum dan jumlah folikel antral pada wanita penderita SOPK.

\section{Metode}

Penelitian ini adalah penelitian observasional analitik dengan pendekatan potong lintang (cross-sectional) terhadap 52 penderita SOPK. Definisi wanita usia subur atau wanita usia reproduksi menurut Departemen Kesehatan Republik Indonesia tahun 2015 adalah wanita yang berusia 15-49 tahun. ${ }^{11}$

Penderita SOPK yang diikutsertakan dalam penelitian ini adalah wanita usia reproduksi, mengalami infertilitas, dan telah didiagnosis SOPK berdasar atas kriteria Rotterdam oleh dokter spesialis obstetri dan ginekologi. Subjek tidak diikutsertakan dalam penelitian ini apabila telah mengalami menopause; memiliki riwayat penyakit tuberkulosis, osteoporosis, artritis, tumor payudara, infeksi pada ginjal atau hati; mengonsumsi metformin, antiandrogen, dan pil kontrasepsi dalam satu minggu terakhir; mengonsumsi suplemen vitamin $\mathrm{D}$, suplemen kalsium, steroid, simetidin, teofilin, diuretik (tiazid); bahan pemeriksaan yang hemolisis, lipemik,dan ikterik pada serum subjekpenelitian. Protokol penelitian telah mendapat persetujuan dari Komite Etik Penelitian Kesehatan RSUP Dr. Hasan Sadikin (RSHS) Bandung dengan Nomor LB.04.01/A05/EC/141//V/2018.Penelitian ini berlangsung sejak bulan Mei sampai dengan Juli 2018 di Klinik Obstetri dan Ginekologi RSHS Bandung.

Kadar 25(OH)D serum berdasarkan Endocrine 
Society dibagi menjadi tiga, yaitu kadar $25(\mathrm{OH})$ $\mathrm{D} \leq 20 \mathrm{ng} / \mathrm{mL}$ disebut defisiensi vitamin $\mathrm{D}$, insufisiensi vitamin D bila kadar 25(OH)D 21-29 $\mathrm{ng} / \mathrm{mL}$, dan kadar 25(OH)D $\geq 30 \mathrm{ng} / \mathrm{mL}$ disebut sufisiensi atau cukup..$^{12}$ Data indeks massa tubuh (IMT) dibagi berdasar atas kriteria Asia Pasifik, yaitu underweight bila memiliki IMT $<18,5 \mathrm{~kg} /$ $\mathrm{m}^{2}$, normoweight bila memiliki IMT 18,5-22,9 $\mathrm{kg} / \mathrm{m}^{2}$, overweight bila memiliki IMT $23,0-24,9$ $\mathrm{kg} / \mathrm{m}^{2}$, sedangkan bila seseorang memiliki IMT $\geq 25 \mathrm{~kg} / \mathrm{m}^{2}$ tergolong obesitas. ${ }^{13}$ Penghitungan folikel antral dilakukan pada hari ke-2 atau ke-3 siklus menstruasi menggunakan ultrasonografi transvaginal. ${ }^{4}$ Hasil penghitungan merupakan jumlah folikel berukuran 2-9 $\mathrm{mm}$ dari kedua ovarium.

Bahan pemeriksaan (BP) pada penelitian ini adalah serum untuk pemeriksaan kadar $25(\mathrm{OH})$ D. BP tersebut berasal dari darah vena subjek penelitian yang diperoleh melalui prosedur flebotomi, selanjutnya BP dibiarkan selama 30 menit sampai terbentuk bekuan. Kemudian, BP disentrifugasi dengan kecepatan $1.000 \mathrm{~g}$ selama 20 menit sampai terbentuk serum. Serum BP disimpan dalam suhu $-80^{\circ} \mathrm{C}$ sampai diperoleh jumlah subjek penelitian sebanyak 52 sampel. Pemeriksaan kadar 25(OH)D serum dilakukan pada bulan Juni 2018 di laboratorium Patologi Klinik RSHS Bandung menggunakan reagen 25-hydroxyvitamin D3(HVD3) dengan metode ELISA kompetitif. Pengumpulan sampel dilakukan pada bulan Mei-Juni 2018. Perhitungan jumlah sampel pada penelitian ini ditentukan dengan rumus ukuran sampel untuk analisis korelasi dengan taraf kepercayaan 95\% dan power test $80 \%$, didapatkan total sampel minimal 52 pasien.

Uji Spearman's correlation digunakan untuk mengetahui korelasi antara kadar 25(OH)D serum dan jumlah folikel antral pada penderita SOPK dan kemaknaan ditentukan berdasar atas nilai $\mathrm{p}<0,05$. Analisis statistik dengan program IBM Statistical package for social sciences (SPSS) version 24.0 for windows.

\section{Hasil}

Karakteristik subjek penelitian dapat dilihat pada Tabel 1. Diagnosis SOPK ditegakkan berdasar atas kriteria Rotterdam. Subjek penelitian sebanyak 52 orang dengan subjek termuda 19 tahun dan subjek tertua 39 tahun. Sebagian besar subjek (50\%) memiliki IMT normal diikuti dengan IMT obes (31\%). Sebagian besar subjek (48\%) tidak melakukan aktivitas fisik. Sebanyak 29 subjek (56\%) termasuk defisiensi 25(OH)D. Berdasar atas hasil pemeriksaan USG transvaginal diperoleh rentang jumlah folikel 12-29 buah.

Korelasi antara jumlah folikel antral dan kadar 25(OH)D serum pada penderita SOPK dapat dilihat pada Tabel 2. Berdasar atas uji

\section{Tabel 1 Karakteristik Subjek Penelitian}

\begin{tabular}{lccc}
\hline \multicolumn{1}{c}{ Variabel } & n (\%) & Median & Min.-Maks. \\
\hline Usia (tahun) & & 29 & $19-39$ \\
Indeks massa tubuh $\left(\mathrm{kg} / \mathrm{m}^{2}\right)$ & $0(0)$ & & \\
$\quad$ Underweight $(<18,5)$ & $26(50)$ & & \\
$\quad$ Normoweight $(18,5-22,9)$ & $10(19)$ & & \\
Overweight $(23,0-24,9)$ & $16(31)$ & & \\
Obese $(\geq 25)$ & $20(38)$ & & \\
Aktivitas fisik & $5(10)$ & & \\
Senam aerobik & $2(4)$ & & \\
Lari & $25(48)$ & & \\
$\quad$ Renang & & & \\
Tidak ada & $29(56)$ & 19,6 & \\
Kadar 25(OH)D serum (ng/mL) & $20(38)$ & & \\
Defisiensi $(\leq 20)$ & $3(6)$ & & \\
Insufisiensi $(21-29)$ & & 12 & \\
Cukup ( $\geq 30)$ & & & \\
Jumlah folikel antral (buah) & & \\
\hline
\end{tabular}


Tabel 2 Korelasi Jumlah Folikel Antral dengan Kadar 25(OH)D Serum pada Penderita Sindrom Ovarium Polikistik

\begin{tabular}{ccc}
\hline & \multicolumn{2}{c}{ Jumlah Folikel Antral } \\
\cline { 2 - 3 } & Koefisien Korelasi & Nilai p \\
\cline { 2 - 3 } Kadar 25(OH)D $(\mathrm{ng} / \mathrm{mL})$ & $-0,867$ & $<0,001^{*}$ \\
\hline
\end{tabular}

Keterangan: * Uji Korelasi Spearman

Tabel 3 Perbandingan Jumlah Folikel Antral pada penderita SOPK berdasar atas Status Vitamin D/250H)D

\begin{tabular}{lcc}
\hline \multirow{1}{*}{ Status 25(OH) D (ng/mL) } & \multicolumn{2}{c}{ Jumlah Folikel Antral (buah) } \\
\cline { 2 - 3 } Defisiensi $(<20)$ & Median (Min.-Maks.) & $<0,001^{*}$ \\
Insufisiensi $(20-29)$ & $19(13-29)$ & \\
Cukup $(\geq 30)$ & $12(12-15)$ \\
\hline
\end{tabular}

Keterangan: *Uji Kruskall Wallis

Korelasi Spearman didapatkan korelasi negatif bermakna dan kekuatan korelasi kuat ( $\mathrm{r}=-0,867$; $\mathrm{p}=0,001)$ antara jumlah folikel antral dan kadar 25(OH)D serum pada penderita SOPK.

Perbandingan jumlah folikel antral pada penderita sindrom ovarium polikistik berdasar atas status vitamin D/25(OH)D serum disajikan pada Tabel 3. Berdasar atas Tabel 3 tampak bahwa pada kelompok dengan kadar 25(OH)D serum $\geq 30 \mathrm{ng} / \mathrm{mL}$ didapatkan median jumlah folikel antral 12 buah, pada kelompok dengan kadar 25(OH)D serum 21-29 ng/mL didapatkan rentang jumlah folikel antral 12-15 buah, dan pada kelompok dengan kadar 25(OH)D serum di bawah $20 \mathrm{ng} / \mathrm{mL}$ didapatkan rentang jumlah folikel antral 13-29 buah.

Berdasar atas hasil analisis posthoc pada Tabel 4 menunjukkan bahwa jumlah folikel

\begin{tabular}{|c|c|}
\hline Status 25(OH)D & Nilai $p$ \\
\hline $\begin{array}{l}\text { Defisiensi (<20 ng/mL) vs } \\
\text { Insufisiensi }(20-29 \mathrm{ng} / \mathrm{mL})\end{array}$ & $<0,001^{*}$ \\
\hline $\begin{array}{l}\text { Defisiensi }(<20 \mathrm{ng} / \mathrm{mL}) \text { vs } \\
\text { Cukup }(\geq 30 \mathrm{ng} / \mathrm{mL})\end{array}$ & $0,002^{*}$ \\
\hline $\begin{array}{l}\text { Insufisiensi }(20-29 \mathrm{ng} / \mathrm{mL}) \text { vs } \\
\text { Cukup }(\geq 30 \mathrm{ng} / \mathrm{mL})\end{array}$ & 1,000 \\
\hline
\end{tabular}

Keterangan: *analisis Posthoc menggunakan Uji Dunn antral kelompok vitamin $\mathrm{D}<20 \mathrm{ng} / \mathrm{mL}$ berbeda bermakna dengan kelompok vitamin D 20-29 $\mathrm{ng} / \mathrm{mL}$ dan $\geq 30 \mathrm{ng} / \mathrm{mL}$, sedangkan jumlah folikel antral kelompok vitamin D 20-29 ng/mL dan $\geq 30 \mathrm{ng} / \mathrm{mL}$ tidak menunjukkan perbedaan yang bermakna.

\section{Pembahasan}

Hasil penelitian ini menunjukkan rentang usia subjek penelitian adalah 19-39 tahun. Rentang usia pada penelitian ini merupakan rentang usia terbanyak prevalensi SOPK. Wanita dengan rentang usia 19-39 tahun mengalami proses folikulogenesis secara konsisten. Pada SOPK terdapat gangguan oligo/anovulasi yang mengganggu proses folikulogenesis sehingga penderita SOPK mengalami keluhan gangguan siklus menstruasi dan dapat disertai keadaan infertil. ${ }^{14}$ Pada penelitian ini rentang IMT subjek penelitian adalah $19,0-34,8 \mathrm{~kg} / \mathrm{m}^{2}$. Tampilan klinis terbanyak penderita SOPK, yaitu IMT lebih daripada normal (IMT overweight dan obese). Pada penelitian ini sebagian besar subjek memiliki IMT lebih daripada normal, yaitu sebanyak 10 subjek memiliki IMT overweight dan 16 subjek memiliki IMT obese. Sebanyak 26 subjek penelitian $(50 \%)$ memiliki IMT lebih dari normal, diikuti dengan 26 subjek (50\%) memiliki IMT normal. Indeks massa tubuh lebih daripada normal merupakan tampilan klinis terbanyak pada pasien SOPK. ${ }^{15}$ Pada penderita SOPK yang overweight dan obesitas dapat 
terjadi defisiensi vitamin D karena paparan sinar matahari ke kulit terhalang oleh jaringan adiposa sehingga pembentukan vitamin $\mathrm{D}$ berkurang. ${ }^{16}$ Terdapat 26 subjek penelitian (50\%) memiliki IMT normal yang kemungkinan berkaitan dengan aktivitas fisik yang dilakukan oleh subjek penelitian. Hasil penelitian Shishehgar dkk. ${ }^{17}$ dinyatakan sebanyak 40,8\% subjek penelitian SOPK melakukan aktivitas fisik rutin sehingga menghasilkan IMT normal. ${ }^{17}$

Kadar 25(OH)D memiliki median 19,6 ng/ $\mathrm{mL}$ dengan rentang $<3-33,3 \mathrm{ng} / \mathrm{mL}$ dan sebagian besar subjek penelitian (94,2\%) mempunyai kadar 25(OH)D serum rendah (kadar vitamin D $<30 \mathrm{ng} / \mathrm{mL})$. Hasil penelitian Nikbakht $\mathrm{dkk}^{10}$ telah menunjukkan rerata kadar $25(\mathrm{OH})$ D serum pada SOPK adalah $13 \pm 11,5 \mathrm{ng} / \mathrm{mL}$ yang termasuk defisiensi vitamin D. Vitamin D memiliki peran pada ovarium, yaitu pada proses steroidogenesis hormon seks dan membantu proses pematangan folikel. Defisiensi vitamin D/ 25(OH)D serum pada penderita SOPK dapat menyebabkan gangguan pada steroidogenesis yang menyebabkan kondisi hiperandrogenemia dan aktivitas FSH terhambat sehingga maturasi dan perkembangan folikel terhambat yang tampak sebagai ukuran folikel antral yang kecilkecil dan banyak. ${ }^{18}$

Penderita SOPK mengalami oligo atau anovulasi yang menyebabkan siklus menstruasi tidak teratur serta dapat ditemukan peningkatan kadar anti mullerian hormon (AMH). Hormon AMH disekresikan oleh sel granulosa dan diduga berperan dalam regulasi pematangan folikel oleh gonadotropin. Hormon AMH yang meningkat menyebabkan proses perkembangan folikel menjadi terhambat di akhir fase independen gonadotropin. Akibatnya, pertumbuhan folikel akan terhenti dan menimbulkan morfologi ovarium polikistik. Merhi dkk. ${ }^{19}$ menemukan hubungan negatif antara kadar AMH dan kadar vitamin D serum pada sel granulosa ovarium sehingga semakin tinggi kadar AMH maka semakin rendah kadar vitamin D serum. Hal ini dapat menjelaskan mengapa terjadi defisiensi vitamin D/25(OH)D serum pada penderita SOPK.

Penelitian ini juga mempunyai beberapa keterbatasan, yaitu tidak didapatkan data pola konsumsi makanan yang mengandung vitamin $\mathrm{D}$, jenis warna kulit, dan intensitas paparan sinar matahari yang dapat memengaruhi kadar vitamin D subjek penelitian. Keterbatasan berikutnya, yaitu penelitian ini tidak mengikutsertakan populasi kontrol, tidak dilakukan pemeriksaan hormon AMH pada subjek penelitian, serta tidak dilakukan analisis lanjutan mengenai hubungan sebab akibat pada penelitian ini.

Simpulan, jumlah folikel antral mempunyai korelasi negatif kuat dengan kadar 25(OH) D serum pada penderita SOPK. Pemeriksaan kadar 25(OH)D serum dapat dipertimbangkan untuk mengetahui status vitamin $\mathrm{D}$ penderita SOPK sebagai pertimbangan dalam penanganan lanjutan.

\section{Daftar Pustaka}

1. Azziz R, Carmina E, Chen ZJ, Dunaif A, Laven JSE, Legro RS dkk. Polycystic ovary syndrome. J Nature Rev. 2016;2:1-18.

2. Sriwastva MK, Ganie MA. Polycystic ovarian syndrome: a multi- specialty, multi system galloping epidemic. Diabetes Obes Int J. 2016;1(3):1-4.

3. Lizneva D, Suturina L, Walker W, Brakta S, Jordan LG, Azziz R. The criteria, prevalence and phenotypes of PCOS. Fertil Steril. 2016;106(1):6-15.

4. Santoso B, Puspaningsih NNT, Riawan W. Apakah perbedaan androgen serum menyebabkan perbedaan manifestasi klinik berupa amenorrhea, oligomenorrhea, dan perdarahan uterus disfungsional pada kasus sindrom ovarium polikistik?. Maj Obs Gin Indones. 2008;32:38-41.

5. Fauser B, Tarlatzis BC, Rebar RW, Legro $\mathrm{RS}$, Balen Ah, Lobo $\mathrm{R}$ dkk. Consensus on women's health aspects of PCOS: the Amsterdam ESHRE /ASRM-Sponsored $3^{\text {rd }}$ PCOS Consensus Workshop Group. Fertil Steril. 2012;97(1):28-38.

6. Suhartono R, Sugiarti N. Diagnosis PCOS: kriteria diagnosis spesifik, evaluasi klinis, laboratorik dan USG. Dalam: Permadi W, Djuwantono $\mathrm{T}$, penyunting. Cara mudah penanganan sindrom ovarium polikistik dalam praktik sehari-hari Departemen Obstetri dan Ginekologi Fakultas Kedokteran Universitas Padjadjaran, RSUP Dr. Hasan Sadikin Bandung: Kongres Obstetri dan Ginekologi Indonesia (KOGI) keXVI;2015:17-26.

7. Wolf J, Barnes CL, Aubuchorn M. Polycystic ovarian syndrome: a diagnosis of exclution. Dalam: Pal L, penyunting. Polycystic ovary syndrome: current and emerging concepts. Edisi ke-2. New York: Springer; 2014. hlm. 11-23.

8. Fulghesu AM, Canu E, Porru C, Cappai A. Ultrasound diagnosis criteria of polycystic ovarian syndrome: current guidelines, 
criticism and possible update. Austin J Obstet Gynecol. 2017;4(2):1-6.

9. Nandi A, Sinha N, Ong E, Sonmetz H, Poretsky L. Is there a role for vitamin $\mathrm{D}$ in human reproduction?. Horm Mol Biol Clin Invest. 2016;25(1):15-28.

10. Nikbakht R, Moramezi F, Farhadi S, Cheraghian B. Vitamin D deficiency in infertile women with polycystic ovary syndrome: a case-control study. Int J Pharm Res Allied Sci. 2016;5(2):144-50.

11. Badan Penelitian dan Pengembangan Kesehatan Kementerian Kesehatan RI. Kesehatan Reproduksi. Pusat Data dan Informasi Kementerian Kesehatan Republik Indonesia. Jakarta: KEMENKES Republik Indonesia; 2015.

12. Holick MF, Binkley NC, Bischoff-Ferrari HA, Gordon CM, Hanley DA, Heaney RP, dkk. Evaluation, treatment, and prevention of vitamin D deficiency: an Endocrine Society clinical practice guideline. J Clin Endocrinol Metab. 2011;96:1911-30.

13. Lim JU, Lee JH, Kim JS, Hwang YI, Kim TH, Lim S, dkk Comparison of World Health Organization and Asia-Pacific body mass index classifications in COPD patients. Int J COPD. 2017;12:2465-75.

14. Moy FM, Bulgiba A. High prevalence of vitamin D insufficiency and its association with obesity and metabolic syndrome among
Malay adults in Kuala Lumpur, Malaysia. BMC Public Health. 2011;11:735.

15. Sidabutar E, Halim B, Siregar MFG, Lutan D, Adenin I, Kaban Y. Vitamin D levels in women with polycystic ovary syndrome. ASPIRE Conference Proceedings, the $6^{\text {th }}$ Congress of the Asia Pacific Initiative on Reproduction, KnE Medicine; 08-10 April 2016; Jakarta: ASPIRE; 2016. hlm. 125-132. DOI 10.18502/ kme.v1i1.547

16. Bellia A, Garcovich C, D'Adamo M, Lombardo M, Tesauro M, Donadel G dkk. Serum 25-hydroxyvitamin D levels are inversely associated with systemic inflammation in severe obese subjects. J Int Emerg Med. 2013;8(1):33-40.

17. Shishehgar F, Tehrani FR, Mirmiran P, Hajian S, Baghestani AR, Moslehi N. Factors influencing physical activity in women with polycystic ovary syndrome in comparison to eumenorrheic non hirsute women. Global J Health Sci. 2016;8(10):127-34.

18. Montes LD, Catena MR, Faus JC. Polycysic ovary syndrome and vitamin $\mathrm{D}$, where do we stand? J Annals Adv Med Sci. 2018;2(1):R15.

19. Merhi Z, Doswell A, Krebs K, Cipolla M. Vitamin D alters genes involved in follicular development and steroidogenesis in human cumulus granulosa cells. J Clin Endocrinol Metab. 2014;99(6):E1137-45. 